\title{
Evaluation of Risk Related to MTHFR 677C $>$ T Gene Polymorphism in Migraine Patients in Kashmiri Population
}

\author{
Arshad A. Pandith1\#, Irfan Y. Wani2 ${ }^{* \#}$, Iqbal Qasim11, Zafar A. Shah ${ }^{3}$, Saleem Sheikh² \\ ${ }^{1}$ Advanced Centre for Human Genetics, Sher-i-Kashmir Institute of Medical Sciences, Srinagar, Jammu and Kashmir, India \\ ${ }^{2}$ Departments of Neurology, Sher-i-Kashmir Institute of Medical Sciences, Srinagar, Jammu and Kashmir, India \\ ${ }^{3}$ Immunology and Molecular Medicine, Sher-i-Kashmir Institute of Medical Sciences, Srinagar, Jammu and Kashmir, India \\ Email: arshaajizskims@gmail.com, ^drirfanyousuf@gmail.com
}

How to cite this paper: Pandith, A.A., Wani, I.Y., Qasim, I., Shah, Z.A. and Sheikh, S. (2017) Evaluation of Risk Related to MTHFR 677C $>$ T Gene Polymorphism in Migraine Patients in Kashmiri Population. Open Journal of Preventive Medicine, 7, 151-161. https://doi.org/10.4236/ojpm.2017.78012

Received: July 8, 2017

Accepted: August 20, 2017

Published: August 23, 2017

Copyright $\odot 2017$ by authors and Scientific Research Publishing Inc. This work is licensed under the Creative Commons Attribution International License (CC BY 4.0). http://creativecommons.org/licenses/by/4.0/

\section{Open Access}

\begin{abstract}
Objective: Migraine, a common chronic neurological disorder involves a pathophysiology having both multiple genetic and environmental factors. 5, 10 Methylenetetrahydrofolate reductase (MTHFR) involved in folate metabolism has an important role in a cell for folate availability which is critical for DNA integrity. Methods: This case-control study conducted in Srinagar, Kashmir (North India) between 2013 and 2015 was designed to evaluate risk induced due to MTH-FR 677C>T gene polymorphisms to contribute in susceptibility for migraine in Kashmir population (North India). Using the polymerase chain reaction-restriction fragment length polymorphism (PCR-RFLP) method, we tested the genotype distribution of 100 migraine patients in comparison with 120 healthy migraine-free controls from the same geographical region. Results: The genotypic frequencies of the patients and controls were not significantly associated ( $p>0.05)$. Higher distribution of TT mutant genotype was found in controls as against the cases (5\% versus $1 \%$ ) but association was not significant ( $\mathrm{p}>0.05)$. Per copy frequency of $\mathrm{T}$ allele (Val) was found to be 0.14 in cases versus 0.19 in controls $(\mathrm{p}<0.05)$. Higher frequency of variant genotypes was found more in controls as compared to migraine with aura as $33.3 \%$ versus $12 \%$ respectively ( $\mathrm{p}>0.05$ ). Similar scenario was observed when migraine without aura was compared with controls where variant genotype (16\% cases versus $39.0 \%$ controls: $\mathrm{p}>$ 0.05 ) as well as allele frequency was found to be less in cases (cases 0.15 versus 0.19 controls: $\mathrm{p}>0.05$ ). Conclusions: We conclude that MTHFR gene C677T polymorphism has no role in predisposition to the migraine in our population and cannot serve as a predictive factor for the risk of migraine.
\end{abstract}




\section{Keywords}

MTHFR Gene C677T, Migraine, Allele, Kashmir, Neurological Disorder, Kashmir

\section{Introduction}

Migraine, a common neurovascular disorder, has several pathophysiological mechanisms implicated in the genesis of ischemic events in migrainous patients [1]. Typically migraine presents with recurrent headache attacks and various combinations of gastrointestinal and autonomic nervous system symptoms [2] [3]. Migraine headache is a complex, recurrent headache disorder that is one of the most common complaints in neurology practice [4]. There are two main types of migraine and they are migraine without aura and migraine with aura. Migraine without aura is the most common type, accounting for more than $80 \%$ of all migraines. Based on different studies, the overall prevalence of migraine among men and women in the US is estimated at $12 \%$ [5] [6] [7]. In Asia the sex-specific migraine prevalence has been reported as $11.3 \%-14.4 \%$ in women and $3.6 \%-6.7 \%$ in men [8].

Migraine is a disease impacted by an intracranial vasospasm followed by the maximum dilatation of extra and intra-cranial arteries responsible for pain [9] [10] [11]. During episodes of migraine attacks the platelet activation and plasma coagulability are increased [12], which strongly supports the idea that genes affecting vascular endothelial function could play a prominent role in cerebral blood flow changes occurring in patients with migraine, contributing to the aetiology of the migraine [13]. Migraine pathophysiology involves both multiple genetic and environmental factors. Gene variants in the methylene tetrahydrofolate reductase gene (MTHFR 677C $>$ T polymorphism, rs1801133) appear to play important roles in the vascular oxidative stress response [14]. The enzyme methylene tetrahydrofolate reductase (MTHFR, EC 1.5.1.20) is involved in folate metabolism, catalyzing the reduction of 5 - 10 methyl tetrahydrofolate to 5-methyltetrahydrofolate, an essential substrate for the methylation of Hcy to methionine. The common C677T substitution in MTHFR results in an aminoacid replacement $(\mathrm{A} 222 \mathrm{~V})$ in the catalytic domain that leads to increased enzyme thermolability and concomitant activity reduction [15]. Studies on the association between the MTHFR 677C>T [3] [12]-[23] polymorphism and migraine, including aura status, have yielded conflicting results often partly due to heterogeneous clinical phenotypes among patients diagnosed with migraine or are affected by various ethnic backgrounds. Keeping in view the ethnic nature of our population, a case-control study was designed first time to observe the impact of MTHFR $677 \mathrm{C}>\mathrm{T}$ gene polymorphism in migraine patients our region (Kashmir, North India). 


\section{Materials and Methods}

This study included 100 patients diagnosed with migraine and 120 healthy controls which were selected from the same geographical region, and was conducted in the Sher-I-Kashmir Institute of Medical Sciences, (SKIMS) Srinagar, Kashmir (North India) in the Department of Neurology and Department of Immunology and Molecular Medicine during the year 2013 and 2015. Clearance from local SKIMS ethical committee was taken prior to start of study. Migraine was diagnosed according to the criteria from the International Headache Society [16]. A detailed medical history was obtained from each patient, and all study participants thoroughly taken for a physical examination. The migraine patients who had any cardiovascular or cerebrovascular disease or hypertension, and smoked were excluded from this study. All patients with migraine were unrelated. Control subjects, who had never experienced a migraine headache, and had no family history of migraine, were selected from the outpatient-neurology clinic. The present study was approved by the Ethical Committee of the Institute (SKIMS).

Blood samples were taken from both the groups and a written pre informed consent was obtained from all the cases and controls.

\subsection{Extraction of Genomic DNA}

$5 \mathrm{ml}$ of peripheral blood was obtained from each subject in ethylenediaminetetra acetic acid (EDTA) containing vials $(200 \mu \mathrm{l}$ of $0.5 \mathrm{M}, \mathrm{pH}=8.0)$ and stored at $-20^{\circ} \mathrm{C}$ till further for DNA extraction use. DNA was extracted from the blood of migraine patients and healthy controls by using DNA Extraction kit (Zymo Research Corporation, USA) as well as salting out method.

\subsection{Polymerase Chain Reaction for Amplification of MTHFR Gene}

To amplify MTHFR, we used genomic DNA: $250 \mathrm{ng} / \mathrm{ml}, 1 \mathrm{X}$ PCR buffer: 100 $\mathrm{mM}$ Tris- $\mathrm{HCl}, \mathrm{pH} 8.3 ; 500 \mathrm{mM} \mathrm{KCl} ; 15 \mathrm{mM} \mathrm{MgCl}_{2}$; deoxyribonucleotide triphosphate (Cinnagen Co., Tehran, Iran): 10 mM dATP; $10 \mathrm{mM} \mathrm{dCTP;} 10 \mathrm{mM}$ dGTP; $10 \mathrm{mM}$ dTTP, primers (Sigma-Aldrich, USA): $10 \mathrm{pM}$ in sterile deionized water and Taq DNA polymerase $5 \mathrm{U} / \mathrm{ml}$ (Biotools, Madrid, Spain). The set of primers previously reported were used for the amplification of the 494-bp target region within the MTHFR gene with forward primer 5' GGTCAGAAGCATATCAGT CA T GAG-3' and the reverse primer 5'-CTGGGAAGAACTCAGCGAACTCAG-3' [17] and thermal conditions used were as follows: one initial denaturation step at $94^{\circ} \mathrm{C}$ for $7 \mathrm{~min}$, followed by 35 cycles of denaturation for $30 \mathrm{~s}$ at $94^{\circ} \mathrm{C}, 30 \mathrm{~s}$ of annealing at $58^{\circ} \mathrm{C}$, and $30 \mathrm{~s}$ of extension at $72^{\circ} \mathrm{C}$, followed by a final elongation cycle at $72^{\circ} \mathrm{C}$ for $5 \mathrm{~min}$.

\subsection{Restriction Fragment Length Polymorphism (RFLP)}

For RFLP, 10 ul PCR product of $490 \mathrm{bp}$ was digested with $\operatorname{Hinf} \mathrm{I}$ ( $5 \mathrm{U}$ at $37^{\circ} \mathrm{C}$ for $16 \mathrm{~h}$ ) (Fermentas, USA). In the case of MTHFR C677T polymorphism, the wildtype CC (Ala/Ala) produced products of size 394-bp and 100-bp bands, while 
the TT (Val/Val) variant was identified by 229-, 165- and 100-bp bands and the heterozygous CT (Ala/Val) variant displayed all four bands of sizes $394 \mathrm{bp}, 229$ bp, $165 \mathrm{bp}$, and $100 \mathrm{bp}$. DNA fragments after digestion were subjected to electrophoresis on a $2 \%-3 \%$ agarose gel and visualized with ethidium bromide in gel documentation system (Cell Bioscience FlourChem HD2). For quality control, each PCR reaction used distilled water instead of DNA as a negative control, and more than $10 \%$ of the samples were analyzed twice for reproducibility of results.

\section{Statistical Analysis}

The cases and controls were compared using the chi square test for categoric variables, such as sex and smoking status, of the demographic variables. A goodness-of-fit chi-square test was used to determine whether the polymorphisms were in Hardy-Weinberg equilibrium between cases and controls. Odds ratios (OR) were used as estimates of the relative risk, and $95 \%$ confidence intervals (CI) were calculated to estimate the association between certain genotypes or other related risk factors of migraine. Statistical significance was considered when $\mathrm{p} \leq$ 0.05 .

\section{Results}

This study was a hospital based case-control study comprising of 100 migraine patients which were frequency matched to gender with 120 healthy controls from the same geographic region. 31 (31\%) migraine patients were males and 69 (69\%) females as against 35 (29.1\%) and 85 (70.9\%) in healthy controls respectively. No specific gender related differences were observed between the groups ( $\mathrm{p}>0.05)$. Out of 100 cases taken in this study, 53 (53\%) were having migraine without aura and 47 (47\%) had migraine with aura. Demographic features of the studied cases like age distribution, residence, and marital status are given in $\mathrm{Ta}$ ble 1 .

The genotypic frequencies of the CC, CT and TT genotypes in the patient group were $73 \%, 26 \%$ and $1 \%$ as compared to controls with frequencies of $66.67 \%, 28.33 \%$, and $5 \%$ respectively $(\mathrm{p}>0.05)$. The distribution of MTHFR C667T variant genotypes $(\mathrm{CT}+\mathrm{TT})$ in patients was lower $(27.0 \%)$ compared with higher frequency in the control group (33.3\%) but no statistical difference was found ( $p>0.05)$ (Table 2). Higher distribution of TT mutant genotype was found in controls as against the cases (5\% versus $1 \%$ ) but association was not significant ( $p>0.05$ ). Per copy frequency of T allele (Val) was found to be 0.14 in cases versus 0.19 in controls while as for $\mathrm{C}$ allele (Ala), the distribution was seen as 0.86 and 0.81 in cases and controls respectively ( $\mathrm{p}<0.05)$. Further, no significant differences were found in the distribution of genotypes/alleles with respect to any demographic parameters list in Table 1.

Migraine patients were further stratified into migraine with aura and without aura and compared to controls (Table 3). Higher frequency of variant genotypes 
Table 1. Distribution analysis of selected demographic factors in migraine cases and controls.

\begin{tabular}{cccc}
\hline Demographic Feature & No. of Patients (\%) & No. of Healthy Controls (\%) & P Value \\
\hline Age & $82(82)$ & $80(66.66)$ & 0.01 \\
$\leq 40$ & $18(18)$ & & \\
$>40$ & & $35(29.3)$ & 0.8 \\
Sex & $31(31.0)$ & $85(70.9)$ & 0.4 \\
Male & $69(69.0)$ & $40(33.33)$ & $80(66.66)$ \\
Female & $38(38)$ & & $75(62.5)$ \\
Residence & $62(62)$ & $45(37.5)$ & 0.0 \\
Rural & & \\
Urban & $68(68)$ & \\
Marital status & $32(32)$ & \\
Married & & \\
Unmarried & $47(47.0)$ & & \\
Type & $53(53.0)$ &
\end{tabular}

Table 2. Genotypic distribution of MTHFR C677T gene polymorphism in migraine cases and controls.

\begin{tabular}{|c|c|c|c|c|c|c|}
\hline SNP & Model & Genotype & $\begin{array}{c}\text { Controls } \\
\mathrm{n}=120\end{array}$ & $\begin{array}{c}\text { Cases } \\
\mathrm{n}=100\end{array}$ & $\begin{array}{l}\text { OR (95\% Confidence } \\
\text { Interval ) }\end{array}$ & $P$ Value \\
\hline & \multirow{3}{*}{ Co-Dominant } & CC (Ala) & $80(66.67 \%)$ & $73(73 \%)$ & Reference & \\
\hline & & CT (Ala/Val) & $34(28.33 \%)$ & $26(26 \%)$ & $1.19(0.93-1.52)$ & 0.6 \\
\hline & & $\mathrm{TT}(\mathrm{Val} / \mathrm{Val})$ & $06(5 \%)$ & $01(1 \%)$ & $5.48(1.97-15.17)$ & 0.1 \\
\hline & \multirow{2}{*}{ Dominant } & CC & $80(66.67 \%)$ & $73(73 \%)$ & Reference & \multirow{2}{*}{0.3} \\
\hline & & $\mathrm{CT} / \mathrm{TT}$ & $40(33.33 \%)$ & $27(27 \%)$ & $1.35(1.01-1.81)$ & \\
\hline & \multirow{2}{*}{ Recessive } & $\mathrm{CC} / \mathrm{CT}$ & $114(95 \%)$ & $99(99 \%)$ & Reference & \multirow{2}{*}{0.1} \\
\hline & & TT & $06(5 \%)$ & $01(1 \%)$ & $5.21(1.77-15.32)$ & \\
\hline \multicolumn{7}{|l|}{ Allele } \\
\hline & Per Copy Frequency & $\mathrm{C}$ & $194(0.81)$ & $172(0.86)$ & Reference & - \\
\hline & Per Copy Frequency & $\mathrm{T}$ & $46(0.19)$ & $28(0.14)$ & $1.46(1.15-1832)$ & 0.1 \\
\hline
\end{tabular}

was found more in controls as compared to migraine with aura as $33.3 \%$ versus $12 \%$ respectively but did not achieve statistical significance $(p>0.05)$. Similar scenario was observed when migraine without aura was compared with controls where with genotypes as well as allele frequency was found to be less in cases (16\% cases versus $33.3 \%$ controls) Table 3. Moreover, migraine types were compared together where genotype and per copy allele frequency were found to be almost in equal proportion (16\%: 0.15 Migraine without Aura versus 12\%; 0.13 Migraine with Aura) and the difference between the two groups was insignificant $(\mathrm{p}>0.05)($ Table 4$)$.

\section{Discussion}

Migraine a chronic neurological disorder affecting mostly women [18] presents 
Table 3. Genotypic frequency of MTHFR C677T gene polymorphism in migraine sub class cases and controls.

\begin{tabular}{|c|c|c|c|c|}
\hline SNP & Migraine with Aura & Controls & & P Value \\
\hline $\mathrm{CC}$ & $35(35 \%)$ & $80(66.67 \%)$ & Reference & \\
\hline $\mathrm{CT}$ & $12(12 \%)$ & $34(28.33 \%)$ & $1.23(0.84-1.79)$ & 0.7 \\
\hline $\mathrm{TT}$ & $0(00 \%)$ & $06(05 \%)$ & 0 & 0.1 \\
\hline $\mathrm{C}$ & $82(0.87)$ & $194(0.81)$ & Reference & \\
\hline \multirow[t]{2}{*}{$\mathrm{T}$} & $12(0.13)$ & $46(0.19)$ & $1.62(1.15-2.27)$ & 0.1 \\
\hline & Migraine without Aura & Controls & & P Value \\
\hline $\mathrm{CC}$ & $37(37 \%)$ & $80(66.67 \%)$ & Reference & \\
\hline $\mathrm{CT}$ & $15(15 \%)$ & $34(28.33 \%)$ & $1.04(0.72-1.49)$ & 1.0 \\
\hline $\mathrm{TT}$ & $01(01 \%)$ & $06(05 \%)$ & $2.77(2.19-3.46)$ & 0.4 \\
\hline $\mathrm{C}$ & $89(0.84)$ & $194(0.81)$ & Reference & \\
\hline $\mathrm{T}$ & $16(0.15)$ & $46(0.19)$ & $1.31(0.96-1.78)$ & 0.4 \\
\hline
\end{tabular}

Table 4. Association of MTHFR C677T gene polymorphism polymorphism in migraine without aura in relation to migraine cases.

\begin{tabular}{ccccc}
\hline SNP & Migraine without Aura & Migraine with Aura & & P Value \\
\hline CC & $37(37 \%)$ & $35(35 \%)$ & Reference & $0.84(0.54-1.32)$ \\
CT & $15(15 \%)$ & $12(12 \%)$ & & 0.8 \\
TT & $01(01 \%)$ & $0(00 \%)$ & Reference & 0.6 \\
C & $89(0.84)$ & $82(0.87)$ & $0.81(0.53-1.22)$ & $0.12(0.13)$ \\
T & $16(0.15)$ & & \\
\hline
\end{tabular}

with recurrent headache attacks and various combinations of gastrointestinal and autonomic nervous system symptoms [3]. Migraine pathophysiology involves both multiple genetic and environmental factors [19]. MTHFR 677C $>\mathrm{T}$ polymorphism (rs1801133) appear to play important roles in the vascular oxidative stress response [20]. Conflicting results have been reported across the world by various studies on the association between the MTHFR 677C $>\mathrm{T}$ [21]-[29] polymorphism and migraine. This case-control study, first of its kind from a region with ethnic background was performed to estimate the contribution of the MTHFR C677T polymorphism to the risk of developing migraine in the Kashmiri population.

This study indicated a lack of association between the migraine patients and controls as evidenced by the approximately equal distribution of genotypes among two groups (73\%, 26\% and $01 \%$ cases versus controls $66.67 \%, 28.33 \%$, and $5 \%$ ). The same scenario is consistent with various studies conducted in several ethnic groups [30] [31]. Further two other studies conducted in different ethnic backgrounds found no association of MTHFR C667T with migraine and were in accordance with our study [32] [33]. On the other hand various other previous studies found a significant association between the MTHFR C667T variant and 
migraine and therefore differ with our report [34] [35] [36]. It seems a wide variation and conflicting results arrive may in part be due to the often heterogeneous clinical phenotypes among patients diagnosed with migraine.

There is evidence where large set of data supports the concept that migraine is partially associated with cerebral blood circulation disturbances [33]. Our study also coincides with Oterino et al. [37] who found no association of the TT-genotype in Spanish migraineurs overall, but a two-fold risk of migraine with aura was reported to be associated with the $\mathrm{T}$-allele among the patients which contradicts our findings where we found no significance in the control and migraine with aura. In this study no significant differences were found when migraine patients were further stratified into migraine with aura and without aura and compared to controls. In contrast higher frequency of variant genotypes was found more in controls as compared to migraine with aura as $33.3 \%$ versus $12 \%$ respectively. Consistently, Bottini et al. [38] reported no association between this polymorphism in MTHFR and migraine, or its sub-groups, in an Italian prospective study. More recently, a meta-analysis combining all studies assessing the association of MTHFR C677T polymorphism with migraine further suggests that the TT-genotype is a genetic risk factor for migraine with aura, but not to migraine overall [39]. Our results also show complete concordance with another report from Portuguese population, where no risk was found either in heterozygous or homozygous MTHFR C677T carriers to migraine. The same study by Anabela Ferro et al. (2008) [40] did not show an increased risk when a stratified analysis into migraine with aura and migraine without aura sub-groups was performed and this in agreement with our study observed which depicted rather an inverse proportion of the risk with variant $\mathrm{T}$-allele between the migraine sub-group and the controls, with lower frequency of the T-allele in both groups although it could not achieve statistical significance. The same trend has been observed by yet another study conducted by Todt et al. in the German population [32].

Moreover, we compared migraine aura with without aura and independently against controls where genotype and per copy allele frequency were found to be almost in equal proportion and the difference between the two groups was insignificant $(p>0.05)$. These results completely rule out the possibility of an association between MTHFR 677TT genetic polymorphism and migraine in our population. This apparent contradiction envisaged by various studies may be due the complex migraine pathophysiology involving both neuronal and vascular dysfunctions [41]. We may thus infer that the TT genotype may slightly reduce the risk for migraine aura or without aura in our patients but these needs to be validated in a large series of samples. The present study evaluated a selected SNP from the MTHFR gene which although has been shown to play a vital role in predisposition of various diseases but limitation of our study was that there are other related sequence variations in same gene which can have a cumulative impact on the outcome of a disease when studied together. Therefore, other 
SNPs in MTHFR need to be analyzed more in cohort studies in migraine patients.

\section{Conclusion}

We conclude that MTHFR 677TT is not associated with a risk for the development of migraine in our group of patients from our population. It is assumed that MTHFR 677TT cannot serve as a predictive factor for the risk of migraine and/or to predict the clinical presentation of the patients with migraine.

\section{Acknowledgements}

We are grateful to the technical staff of the Department of Neurology for helping in the procurement of samples.

\section{Compliance with Ethical Standards}

Funding: Funding of this study was supported by Sher-I-Kashmir Institute of Medical Sciences, Srinagar, Kashmir, India, 190011.

Conflict of Interest: All authors declare no conflict of interest.

Ethical approval: All procedures performed in studies involving human participants were in accordance with the ethical standards of the institutional and/ or national research committee and with the 1964 Helsinki declaration and its later amendments or comparable ethical standards.

\section{References}

[1] Lea, R.A., Ovcaric, M., Sundholm, J., MacMillan, J. and Griffiths, L.R. (2004) The Methylenetetrahydrofolate Reductase Gene C677t Influences Susceptibility to Migraine with Aura. BMC Medicine, 2, 3-7. https://doi.org/10.1186/1741-7015-2-3

[2] Haut, S.R., Bigal, M.E. and Lipton, R.B. (2006) Chronic Disorders with Episodic Manifestations: Focus on Epilepsy and Migraine. The Lancet Neurology, 5, 148-157.

[3] Silberstein, S.D. (2004) Migraine. The Lancet, 363, 381-391.

[4] World Health Organization (2011) Atlas of Headache Disorders and Resources in the World 2011. World Health Organization, Geneva.

[5] Stewart, W.F., Lipton, R.B., Celentano, D.D. and Reed, M.L. (1992) Prevalence of Migraine Headache in the United States. Relation to Age, Income, Race, and Other Sociodemographic Factors. JAMA, 267, 64-69. https://doi.org/10.1001/jama.1992.03480010072027

[6] Lipton, R.B., Bigal, M.E., Diamond, M., Freitag, F., Reed, M.L. and Stewart, W.F. (2007) AMPP Advisory Group. Migraine Prevalence, Disease Burden, and the Need for Preventive Therapy. Neurology, 68, 343-349. https://doi.org/10.1212/01.wnl.0000252808.97649.21

[7] Lipton, R.B., Stewart, W.F., Diamond, S., Diamond, M.L. and Reed, M. (2001) Prevalence and Burden of Migraine in the United States, Data from the American Migraine Study II. Headache, 41, 646-657. https://doi.org/10.1046/j.1526-4610.2001.041007646.x

[8] Wang, S.J. (2003) Epidemiology of Migraine and Other Types of Headache in Asia. Current Neurology and Neuroscience Reports, 3, 104-108. 
https://doi.org/10.1007/s11910-003-0060-7

[9] Chiodini, B.D., Barlera, S., Franzosi, M.G. and Rognoni, G.I. (2001) Geni di suscettibilità all'infarto, una revisione della letteratura. Italian Heart Journal, 2, 935-944.

[10] Colucci d'Amato, C., Alfano, V., Giordano, E., Marmolo, T. and Pizza, V. (1997) Le Cefalee. 2nd Edition, Idelson, Napoli.

[11] Bianchi, A., Pitari, G., Amenta, V., Giuliano, F., Gallina, M., Costa, R. and Ferlito, S. (1996) Endothelial, Haemostatic and Haemorheological Modifications in Migraineurs. Artery, 22, 93-100.

[12] Corral, J., Iniesta, J.A., Gonzà-Conejero, R., Lozano, M.L., Rivera, J. and Vicente, V. (1998) Migraine and Prothrombotic Genetic Risk Factors. Cephalalgia, 18, 257. https://doi.org/10.1046/j.1468-2982.1998.1805257.x

[13] Colson, N.J., Fernandez, F. and Griffiths, L.R. (2007) Migraine Genetics and Prospects for Pharmacotherapy. Drug Development Research, 68, 282-293. https://doi.org/10.1002/ddr.20192

[14] Peroutka, S.J. (1997) Dopamine and Migraine. Neurology, 49, 650-656. https://doi.org/10.1212/WNL.49.3.650

[15] Frosst, P., Blom, H.J., Milos, R., Goyette, P., Sheppard, C.A., Matthews, R.G., Boers, G.J., den Heijer, M., Kluijtmans, L.A. and van den Heuvel, L.P. (1995) A Candidate Genetic Risk Factor for Vascular Disease, a Common Mutation in Methylenetetrahydrofolate Reductase. Nature Genetics, 10, 111-113. https://doi.org/10.1038/ng0595-111

[16] Headache Classification Committee of the International Headache Society (IHS) (2013) The International Classification of Headache Disorders. 3rd Edition, Beta Version, Cephalalgia, 33, 629-808.

[17] Cicek, M.S., Nock, N.L., Li, L., Conti, D.V., Casey, G. and Witte, J.S. (2004) Relationship between Methylenetetrahydrofolate Reductase C677T and A1298C Genotypes and Haplotypes and Prostate Cancer Risk and Aggressiveness. Cancer Epidemiology, Biomarkers \& Prevention, 13, 1331-1336.

[18] Lipton, R.B. and Bigal, M.E. (2005) The Epidemiology of Migraine. American Journal of Medicine, 118, 3S-10S.

[19] Mulder, E.J., Van Baal, C., Gaist, D., Kallela, M., Kaprio, J., Svensson, D.A., Nyholt, D.R., Martin, N.G., MacGregor, A.J., Cherkas, L.F., Boomsma, D.I. and Palotie, A. (2003) Genetic and Environmental Influences on Migraine, a Twin Study across Six Countries. Twin Research, 6,422-431. https://doi.org/10.1375/136905203770326420

[20] Tietjen, E.G. (2007) Migraine and Ischaemic Heart Disease and Stroke, Potential Mechanisms and Treatment Implications. Cephalalgia, 27, 981-987. https://doi.org/10.1111/j.1468-2982.2007.01407.x

[21] Joshi, G., Pradhan, S. and Mittal, B. (2009) Role of the ACE ID and MTHFR C677T Polymorphisms in Genetic Susceptibility of Migraine in a North Indian Population. Journal of the Neurological Sciences, 277, 133-137.

[22] Cakmak, E.A., Cataloluk, O., Yoldas, T., Herken, H. and Barlas, O. (2003) Migraine and Angiotensinconverting Enzyme Association in Turkish Patients. Pain Clinics, 15, 473-477. https://doi.org/10.1163/156856903770196881

[23] Kara, I., Ozkok, E., Aydin, M., Orhan, N., Cetinkaya, Y., Gencer, M., Kilic, G. and Tireli, H. (2007) Combined Effects of ACE and MMP-3 Polymorphisms on Migraine Development. Cephalalgia, 27, 235-243.

https://doi.org/10.1111/j.1468-2982.2006.01269.x

[24] Kowa, H., Fusayasu, E., Ijiri, T., Ishizaki, K., Yasui, K., Nakaso, K., Kusumi, M., Ta- 
keshima, T. and Nakashima, K. (2005) Association of the Insertion/Deletion Polymorphism of the Angiotensin I-Converting Enzyme Gene in Patients of Migraine with Aura. Neuroscience Letters, 374, 129-131.

[25] Lea, R.A., Ovcaric, M., Sundholm, J., Solyom, L., Macmillan, J. and Griffiths, L.R. (2005) Genetic Variants of Angiotensin Converting Enzyme and Methylenetetrahydrofolate Reductase May Act in Combination to Increase Migraine Susceptibility. Brain Research. Molecular Brain Research, 136, 112-117.

[26] Lin, J.J., Wang, P.J., Chen, C.H., Yueh, K.C., Lin, S.Z. and Harn, H.J. (2005) Homozygous Deletion Genotype of Angiotensin Converting Enzyme Confers Protection against Migraine in Man. Acta Neurologica Taiwanica, 14, 120-125.

[27] Paterna, S., Di Pasquale, P., D’Angelo, A., Seidita, G., Tuttolomondo, A., Cardinale, A., Maniscalchi, T., Follone, G., Giubilato, A., Tarantello, M. and Licata, G. (2000) Angiotensin Converting Enzyme Gene Deletion Polymorphism Determines an Increase in Frequency of Migraine Attacks in Patients Suffering from Migraine without Aura. European Neurology, 43, 133-136. https://doi.org/10.1159/000008151

[28] Schürks, M., Zee, R.Y.L., Buring, J.E. and Kurth, T. (2009) ACE D/I Polymorphism, Migraine, and Cardiovascular Disease in Women. Neurology, 72, 650-656. https://doi.org/10.1212/01.wnl.0000342517.97178.f6

[29] Tronvik, E., Stovner, L.J., Bovim, G., White, L.R., Gladwin, A.J., Owen, K. and Schrader, H. (2008) Angiotensin Converting Enzyme Gene Insertion/Deletion Polymorphism in Migraine Patients. BMC Neurology, 8, 4.

https://doi.org/10.1186/1471-2377-8-4

[30] Kurth, T., Gaziano, J.M., Cook, N.R., Logroscino, G., Diener, H.C. and Buring, J.E. (2006) Migraine and Risk of Cardiovascular Disease in Women. JAMA, 296, 283 291. https://doi.org/10.1001/jama.296.3.283

[31] Kara, I., Sazei, A., Ergul, E., Kaya, G. and Kilie, G. (2003) Association of the C677T and A1298C Polymorphisms in the 5, 10 Methylenetetrahy-drofolate Reductase Gene in Patients with Migraine Risk. Brain Research. Molecular Brain Research, $111,84-90$.

[32] Todt, U., et al. (2006) MTHFR C677T Polymorphism and Migraine with Aura. Annals of Neurology, 60, 621-622.

[33] Kaunisto, M.A., Kallela, M., Hämäläinen, E., Kilpikari, R., Havanka, H., Harno, H., Nissilä, M., Säkö, E., Ilmavirta, M., Liukkonen, J., Teirmaa, H., Törnwall, O., Jussila, M., Terwilliger, J., Färkkilä, M., Kaprio, J., Palotie, A. and Wessman, M. (2006) Testing of Variants of the MTHFR and ESR1 Genes in 1798 Finnish Individuals Fails to Confirm the Association with Migraine with Aura. Cephalalgia, an International Journal of Headache, 26, 1462-1472.

[34] Kowa, H., Yasui, K., Takeshima, T., Urakami, K., Sakai, F. and Nakashima, K. (2000) The Homozygous C677T Mutation in the Methylenetetrahydrofolate Reductase Gene Is a Genetic Risk Factor for Migraine. American Journal of Medical Genetics, 96, 762-764. https://doi.org/10.1002/1096-8628(20001204)96:6<762::AID-AJMG12>3.0.CO;2-X

[35] Lea, R.A., Ovcaric, M., Sundholm, J., MacMillan, J. and Griffiths, L.R. (2004) The Methylenetetrahydrofolate Reductase Gene Variant C677T Influences Susceptibility to Migraine with Aura. BMC Medicine, 2, 3. https://doi.org/10.1186/1741-7015-2-3

[36] Scher, A.I., Terwindt, G.M., Verschuren, W.M., Kruit, M.C., Blom, H.J., Kowa, H., Frants, R.R., van den Maagdenberg, A.M., van Buchem, M., Ferrari, M.D. and Launer, L.J. (2006) Migraine and MTHFR C677T Genotype in a Population-Based Sample. Annals of Neurology, 59, 372-375. https://doi.org/10.1002/ana.20755 
[37] Oterino, A., Valle, N., Bravo, Y., Muñoz, P., Sánchez-Velasco, P., Ruiz-Alegría, C., Castillo, J., Leyva-Cobián, F., Vadillo, A. and Pascual, J. (2004) MTHFR T677 Homozygosis Influences the Presence of Aura in Migraineurs. Cephalalgia, an International Journal of Headache, 24, 491-494.

[38] Bottini, F., Celle, M.E., Calevo, M.G., Amato, S., Minniti, G., Montaldi, L., Di Pasquale, D., Cerone, R., Veneselli, E. and Molinari, A.C. (2006) Metabolic and Genetic Risk Factors for Migraine in Children. Cephalalgia, 26, 731-737.

https://doi.org/10.1111/j.1468-2982.2006.01107.x

[39] Rubino, E., Ferrero, M., Rainero, I., Binello, E., Vaula, G. and Pinessi, L. (2007) Association of the C677T Polymorphism in the MTHFR Gene with Migraine, a Meta-Analysis. Cephalalgia, 29, 818-825. https://doi.org/10.1111/j.1468-2982.2007.01400.x

[40] Ferro, A., Castro, M.J., Lemos, C., Santos, M., Sousa, A., Pereira-Monteiro, J., et al. (2008) The C677T Polymorphism in MTHFR Is Not Associated with Migraine in Portugal. Disease Markers, 25, 107-113. https://doi.org/10.1155/2008/178679

[41] Pietrobon, D. and Striessnig, J. (2003) Neurobiology of Migraine. Nature Reviews Neuroscience, 4, 386-398. https://doi.org/10.1038/nrn1102

\section{Submit or recommend next manuscript to SCIRP and we will provide best service for you:}

Accepting pre-submission inquiries through Email, Facebook, LinkedIn, Twitter, etc. A wide selection of journals (inclusive of 9 subjects, more than 200 journals)

Providing 24-hour high-quality service

User-friendly online submission system

Fair and swift peer-review system

Efficient typesetting and proofreading procedure

Display of the result of downloads and visits, as well as the number of cited articles

Maximum dissemination of your research work

Submit your manuscript at: http://papersubmission.scirp.org/

Or contact ojpm@scirp.org 